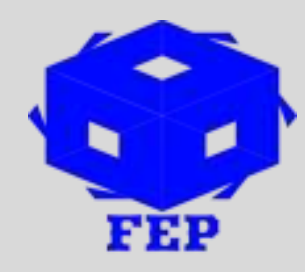

\title{
ANALYSIS OF REWARD PRACTICES AND THEIR INFLUENCE ON EMPLOYEE ENGAGEMENT AMONG SOFTWARE DEVELOPMENT FIRMS IN PAKISTAN
}

\author{
Muhammad Tahir ${ }^{1}$ \\ ${ }^{1}$ Iqra National University, Peshawar, Pakistan
}

*Corresponding Author: Muhammad Tahir

Corresponding Author Email: tahirkhanzaee@ gmail.com

Article Received: 11-05-19

Accepted: 30-05-19

Published: 10-06-19

Licensing Details: Author retains the right of this article. The article is distributed under the terms of the Creative Commons Attribution-NonCommercial 4.0 License (http://www.creativecommons.org/licences/by-nc/4.0/) which permits non-commercial use, reproduction and distribution of the work without further permission provided the original work is attributed as specified on the Journal open access page.

\begin{abstract}
The current study is based on investigation of current reward practices of the software development firms in Pakistan, employee's preference for different type of reward offered, and influence of reward practices on employee's work engagement. The design of the study is cross-sectional and explanatory, and it is based on quantitative approach and survey method. Primary data is collected from staff of 10 selected software development firms located in the city of Islamabad $(n=160)$. Our results indicate that in monetary reward category, employees prefer reward such as enough payments, overtime payments, and transportation allowances which are not adequately provided by the employers. Similarly, in non-monetary reward category, employees prefer reward such as social security, and appreciation and recognition which are not adequately addressed by the employers. Furthermore, results indicate that both monetary reward as well as non-monetary reward has positive and significant effects on employee engagement. Both type of reward explains $66.9 \%$ change in the employee engagement level. Our results imply that software development firms in Pakistan should review their reward practices and give attention to both type of reward.
\end{abstract}

Keywords: Monetary Reward, Non-Monetary Reward, Employee Engagement, Software Firms

\section{INTRODUCTION}

The software development Industry in Pakistan plays important role in economy by creating jobs, paying taxes, and bringing foreign exchange in the country. According to the Pakistan 
Software Export Board (2018), the current estimated value of exporting software and related services is about $\$ 2$ billion per annum which is an increase of $40 \%$ since year 2000 . The industry is facing opportunities such as CPEC project, as well as challenges including high competition. One associated challenge is designing and management of an effective reward system which meets the needs of the industry and enables it to compete at global stage. A well-designed reward system also enables management to direct the right behavior and attitude from employee enabling organization to achieve its strategic objectives (Thompson, Strickland, \& Gamble, 2005). The current study is an analysis of reward practices of the software development firms in Pakistan.

\section{Problem Statement}

Employee engagement is a major issue for many industries and costing large amount of money to the employers. In software development industry, employee's salaries constitute big portion of the total cost of production (approximately 50\%); yet, if employee are not fully engaged, so it do not bring the desired result to the business. Past studies conducted at International level also showed that low work engagement among staff is a global problem (Gallup, 2013; Hewitt, 2013). Employee reward plays important role in shaping employee behavior including their engagement level. The current study is an investigation about the influence of rewarding practices on employee engagement among staff of software development firms in the city of Islamabad, Pakistan.

\section{Background of the Study}

The introduction of the concept of 'total reward' changed the old concept of rewarding employees through cash only (Armstrong, 2007). The 'total reward' concept includes both the monetary as well as non-monetary reward which an organization should be offering to its employees for satisfying their various needs. Past studies found influence of rewarding practices on employee's behavior and attitude such as job satisfaction, job performance, and commitment (Agarwal, 2010; Chaing \& Birtch, 2008; Hofmans, De Gieter \& Pepermans, 2013; Shives \& Scott, 2009; Sweeney \& McFarlin, 2005). The relationship between monetary and non-monetary reward with the employee engagement is also found in previous studies (Thomas, 2009; Waqas \& Saleem, 2014). In current study, the relationship between reward types (monetary and non-monetary) and employee engagement is investigated in the context of software industry in the Pakistan.

\section{Objective of the Study}

The objectives of the study are;

- To identify the gap between the reward practices offered and the type of reward preferred by the employees in the software development firms in Pakistan.

- To test the relationship between monetary reward and the employee engagement.

- To test the relationship between non-monetary reward and the employee engagement

\section{Significance of the Study}

The significance of the current study is that it will enhance understanding about the rewarding practices in the software development firms in the Pakistan. The study will identify the gap between the offered reward and the type of reward preferred by the employees. The study will also extend the literature by testing the relationship between reward practices and 
the employee engagement level. The findings of the current study will be useful for the HR and management of the software development firms. The findings can also be utilized by the consultants, academics, and other service oriented firms in similar field.

\section{LITERATURE REVIEW}

\section{Reward Practices}

The concept of 'total reward' refers to both monetary as well as non-monetary reward (Armstrong, 2007; Nienaber, 2010). The monetary reward is also known as extrinsic reward and is majorly financial in nature (Luthans \& Peterson, 2002). Common type of monetary reward includes cash based transaction between a worker and his/her employer such as cash or cash in kind, commissions, personal bonuses, health allowances and so on. Non-monetary reward is also known as intrinsic reward and is based on the internal feelings of growth, autonomy, satisfaction, and self-competence. Common type of non-monetary reward include recognition, positive supervisory behavior, positive social atmosphere, quality communication, flexible working hours, cooperation, respect, and friendly environment (Sousa-Poza \& Sousa-Poza, 2000; Thomas, 2009). The importance of non-monetary reward is also recognized by the prominent experts in the field of HRM including Pfeffer (1998), Armstrong (2007), and Jeffrey (2002). Some studies even found that in terms of preference, some employees prefer non-monetary reward over the monetary reward (Kube, Marechal, \& Puppe, 2008; Steen, 1997).

\section{Employee Engagement}

Employee engagement can be described as the level of commitment and involvement of an employee towards the organization and its value (Sundaray, 2011). It also refers to the degree to which an individual is attentive to their work and absorbed in the performance of their roles (Saks, 2006). Schaufeli, Salanova, Gonzalez-Roma, \& Bakker (2002) proposed three dimensions of employee engagement including absorption, dedication, and rigor. Accordingly, absorption is about employee's level of immersion and pleasure developed because of work; dedication is about employee's feeling of meaningfulness of work performed; and vigor is about energetic behavior and devotion on part of employee's work (Bakker, 2011). Having an engaged workforce produces favorable outcomes for organization including higher productivity and achievement of organizational goals (AbuKhalifeh \& Som, 2013; Bakker, 2011; Sundaray, 2011). The other favorable outcomes of having an engaged workforce include organizational effectiveness, workforce satisfaction, customer satisfaction, lower absenteeism among staff, and decrease in employee turnover (Evenson, 2014; O'Reilly \& Bahr, 2014; Schaufeli, 2013).

\section{Relationship between Reward Practices and Employee Engagement}

Empirical evidence from past studies shows that rewarding practices have significant effects on employee's attitude (Hofmans, De Gieter \& Pepermans, 2013). Both type of reward including the monetary as well as non-monetary reward are found to be having positive influence on employees. Even though, there is doubt placed on the monetary reward effectiveness, still, there are studies which found positive influence of monetary reward on employee's motivation (Agarwal, 2010; Sweeney \& McFarlin, 2005,). The positive influence of non-monetary reward on employees is also established in literature in terms of 
employee motivation (Mathauer \& Imhoff's 2006); employee performance (Chaing \& Birtch, 2008; Wiscombe, 2002); and organizational competitiveness (Thumbran, 2010).

Past studies found that reward practices including monetary as well as non-monetary reward also have influence on employee's level of engagement (Hewitt, 2013; Shives \& Scott, 2009; Thomas, 2009). For example, a study conducted by Ram and Prabhakar (2011) found that combination of extrinsic as well as intrinsic reward leads to employee engagement. A study conducted in Pakistani manufacturing and service oriented organizations found positive influence of monetary and non-monetary reward on employee level of engagement (Waqas \& Saleem, 2014). A study conducted among bank employees in Pakistan found that reward practices as well as leadership have influence on bank employee level of engagement (Benazir \& Iqbal, 2015). A study conducted in IT industry in India found that both monetary as well as non-monetary reward leads to employee engagement (Rao \& Shaikh, 2017). Based on past studies, it is proposed that both monetary as well as non-monetary reward have significance positive influence on employee's level of engagement. The literature gap is that there are studies conducted on reward practices and employee behavior and attitude including employee engagement, but such studies are not conducted in the software development firms or IT sector context in Pakistan.

\section{Theoretical Model of the Study}

The relationship between rewarding practices including monetary as well as non-monetary reward and employee related outcome can be supported by different theories. One such theory is Herzberg two factor theory which differentiate between hygiene and motivating factors. Accordingly, presence of hygiene factor restrain employee from dissatisfied but do not necessarily lead to motivation; while, presence of motivating factors provide motivation to the employees. Monetary reward such as cash payments are one type of hygiene factor; while, non-monetary reward such as growth is a type of motivating factor. Therefore, based on this theory, it is important that organization offer both type of reward to its employees. The use of monetary reward can be supported by the Maslow's need hierarchy theory since money can satisfy different needs such as food and water which fulfill physiological needs (Wallace \& Zeffane, 2001). Furthermore, when organization offers non-monetary reward, it satisfies higher level needs of employees. Another theory which supports the relationship between employee reward and engagement is the Social Exchange Theory (Saks, 2006). The theory explains that when employee receive different type of reward from the employer, it leads to the feeling of obligation to exercise fair exchange in return which leads to the higher level of employee engagement. Furthermore, the theory explains the relationship between reward and employee engagement through the lens of reciprocal interdependence (Kumar \& Swetha, 2011). Based on the theories mentioned above and the past studies, the study put forward the following theoretical framework. 


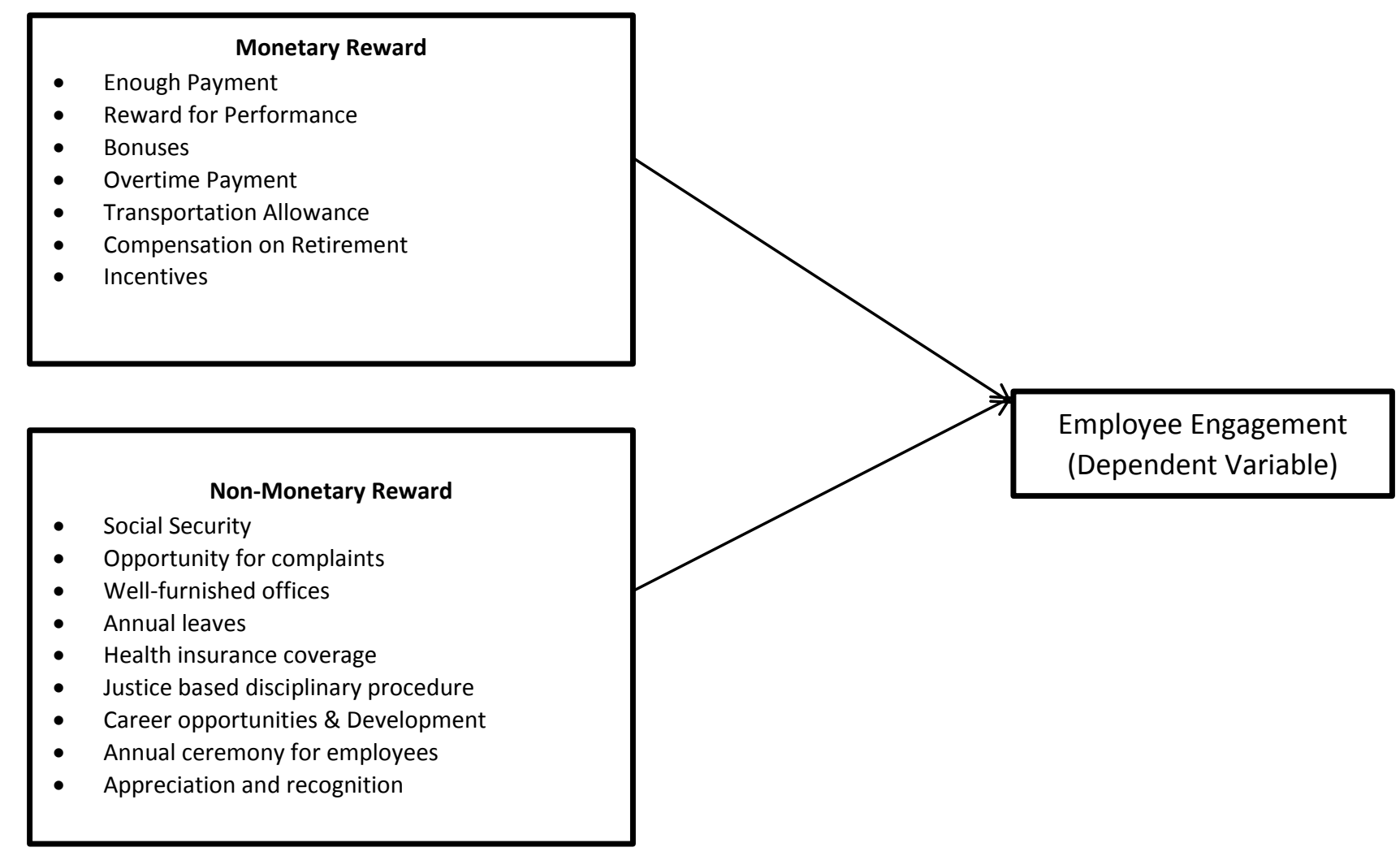

Figure 1: Theoretical Model of the Study

\section{Research Design}

\section{RESEARCH METHODOLOGY}

The design of the current study is cross-sectional, explanatory, and non-experimental. The study is based on cross-sectional data means data is only collected at one point in time. The explanatory design means the study is based on explaining the relationship between reward type and employee engagement. Non-experimental design means there is no modification in work environment of the participants involved.

\section{Research Approach}

The research approach is quantitative. Accordingly, survey is main method used for collecting primary data.

\section{Population and Sampling}

The population of the current study is all software development firms located in the city of Islamabad, Pakistan. Through random sampling, data is collected from 160 staff members from 10 selected software development firms.

\section{Measure}

The monetary and non-monetary reward is measured through 16 items adapted from AlNsour (2012). Employee engagement is measured by 17 items adapted from Maslach, Schaufeli, \& Leiter (2001).

\section{Data Collection}

Data is collected through survey physically distributed among the staff in the selected 
software development firms located in the city of Islamabad, Pakistan. These surveys were later on collected back by the researcher.

\section{Data Analysis}

Data is analyzed using SPSS version 20. Statistical techniques include descriptive statistics, independent sample t-test, correlation, and hierarchical regression analysis.

\section{RESULTS AND DISCUSSION}

\section{Demographic Information of the Survey Participants}

Demographic information of the survey participants are as under.

Table 1

Demographic Information

\begin{tabular}{|c|c|c|}
\hline & Frequency & Percentage \\
\hline \multicolumn{3}{|l|}{ Gender } \\
\hline Male & 112 & 70 \\
\hline Female & 48 & 30 \\
\hline \multicolumn{3}{|l|}{ Age Group } \\
\hline 18 to 25 Years & 93 & 58.1 \\
\hline 25 to 40 Years & 56 & 35.0 \\
\hline 40 to 60 Years & 8 & 5.0 \\
\hline Above 60 Years & 3 & 1.9 \\
\hline \multicolumn{3}{|l|}{ Qualification } \\
\hline Intermediate or Less & 2 & 1.3 \\
\hline Bachelors & 111 & 69.4 \\
\hline Masters & 42 & 26.3 \\
\hline Others & 5 & 3.1 \\
\hline \multicolumn{3}{|l|}{ Role } \\
\hline Software Developer & 88 & 55.0 \\
\hline Software Designer & 58 & 36.3 \\
\hline Support Staff & 9 & 5.6 \\
\hline Others & 5 & 3.1 \\
\hline
\end{tabular}

The demographic information of the survey participants is given in table 1 above. There were 112 male and 48 female in the survey. In terms of age, 93 participants belonged to the age group of 18 to 25 years; 56 belonged to the age group of 25 to 40 years; 8 participants belonged to the age group of 40 to 60 years; and 3 participants belonged to the age group of above 60 years. Qualification wise, 2 participants had intermediate or less qualification; 111 had bachelor level qualification; 42 had master level qualification; and 5 had others level of qualification. In terms of role, 88 were software developers; 58 were software designer; 9 were support staff; and 5 belonged to the other category.

\section{Comparison of Offered and Preferred Reward}

Comparison of offered and preferred reward for monetary and non-monetary reward is as under.

Table 2

Comparative Statistics for Monetary Reward

\begin{tabular}{lccccc}
\hline & \multicolumn{2}{c}{ Monetary Reward-Offered } & \multicolumn{2}{c}{ Monetary Reward-Preferred } & t-stat \\
\cline { 2 - 5 } & Mean & S.D. & Mean & S.D. & $-3.129 * * *$ \\
Enough Payment & 3.7625 & 1.00619 & 4.1312 & 1.09958 & -.360 \\
Reward for Performance & 3.4562 & 1.12628 & 3.5062 & 1.32701 & .179 \\
Bonuses & 3.5313 & 1.15427 & 3.5063 & 1.39179 & $-5.319 * * *$ \\
Overtime Payment & 3.5688 & .96883 & 4.0875 & .99298 & $-4.236^{* * *}$ \\
Transportation Allowance & 3.4000 & .99811 & 3.8750 & .96967 & -.736 \\
Compensation on Retirement & 3.6125 & .92476 & 3.6937 & 1.03399 & $-5.426 * * *$ \\
Incentive & 3.4687 & .88255 & 4.0000 & .93162 & \\
\hline$* \mathrm{P}<0.05, * * \mathrm{P}<0.01, * * * \mathrm{P}<0001$ & & & & &
\end{tabular}




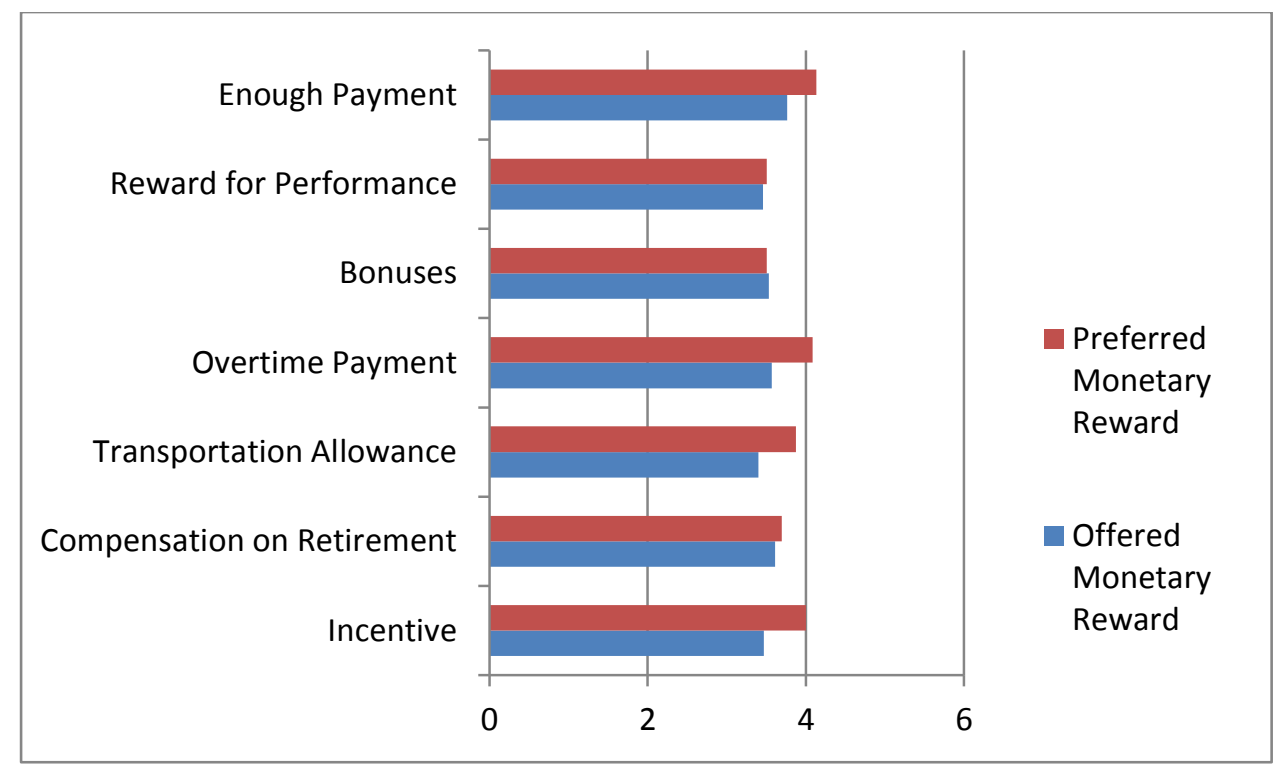

Figure 2: Comparison of Preferred and Offered Monetary Reward

The descriptive statistics and the paired t-statics comparison suggest that in sample firms, some monetary reward were preferred more by the employees but offered less by the employer including enough payment $(\mathrm{t}=-3.129, \mathrm{P}<.05)$; overtime payment $(\mathrm{t}=-5.319, \mathrm{P}<.05)$; transportation allowance $(\mathrm{t}=-4.236, \mathrm{P}<.05)$; and incentives $(\mathrm{t}=-5.426, \mathrm{P}<.05)$. The above analysis suggest that enough payment, overtime payment, transportation allowance, and incentives are those type of monetary reward which are desired by the employees but not adequately provided by the employer.

Table 3

Comparative Statistics for Non-Monetary Reward

\begin{tabular}{|c|c|c|c|c|c|}
\hline & \multicolumn{2}{|c|}{$\begin{array}{c}\text { Non-Monetary Reward- } \\
\text { Offered }\end{array}$} & \multicolumn{2}{|c|}{$\begin{array}{c}\text { Non-Monetary Reward- } \\
\text { Preferred }\end{array}$} & \multirow[b]{2}{*}{ t-stat } \\
\hline & Mean-Offered & S.D. & Mean-Desired & S.D. & \\
\hline Social Security & 3.4250 & 1.02516 & 3.7812 & .87360 & $-3.380 * * *$ \\
\hline Opportunity for Complaints and Suggestions & 3.4500 & 1.03280 & 4.0562 & .87772 & $-5.490 * * *$ \\
\hline Well-furnished Offices & 3.4938 & 1.06397 & 3.7625 & .85036 & $-2.502 * *$ \\
\hline Annual Leaves & 3.5313 & .87539 & 3.4813 & 1.05193 & .497 \\
\hline Health Insurance Coverage & 3.7250 & .83891 & 3.7125 & .98662 & .114 \\
\hline Justice based Disciplinary Procedures & 3.7688 & .91954 & 3.5625 & .84442 & $2.047 *$ \\
\hline Career Opportunities and Development & 3.8938 & .94899 & 3.6398 & .97181 & $2.342 *$ \\
\hline Annual Ceremony for Employees & 3.6000 & .91939 & 4.1242 & 1.02322 & $-4.810 * * *$ \\
\hline Appreciation and Recognition & 3.5500 & .88878 & 4.1304 & 1.03761 & $-6.074 * * *$ \\
\hline
\end{tabular}

\begin{tabular}{|r|r|r|r|r|}
\hline Social Security \\
Op $<0.05, * * \mathrm{P}<0.01, * * * \mathrm{P}<0001$ \\
Well-furnished Offices \\
Annual Leaves \\
Health Insurance Coverage
\end{tabular}

Figure 3: Comparison of Preferred and Offered Non-Monetary Reward 
The descriptive statistics and the paired t-statics comparison also suggest that in sample firms, some non-monetary reward were preferred more but offered less by the employer including social security $(\mathrm{t}=-3.38, \mathrm{P}<.05)$; opportunity for complaints and suggestions $(\mathrm{t}=-$ $5.49, \mathrm{P}<.05)$; well-furnished offices $(\mathrm{t}=-2.50, \mathrm{P}<.05)$; annual ceremony for employees $(\mathrm{t}=-$ 4.81, $\mathrm{P}<.05)$; and appreciation and recognition $(\mathrm{t}=-6.07, \mathrm{P}<.05)$. Furthermore, two type of non-monetary reward including justice based disciplinary procedure $(\mathrm{t}=2.04, \mathrm{P}<.05)$; and career opportunities and development $(\mathrm{t}=2.34, \mathrm{P}<.05)$ were preferred less but offered more by the employers. This analysis suggest that social security, opportunities for complaints and suggestions, well-furnished offices, annual ceremony for employees, and appreciation and recognition are those type of non-monetary reward which are desired more by the employees but less entertained by the employers.

\section{Descriptive Statistics}

Table 4

Descriptive Statistics

\begin{tabular}{lccccccc}
\hline & No of Items & Cronbach Alpha & Mean & Std. Deviation & $\mathbf{1}$ & $\mathbf{2}$ & $\mathbf{3}$ \\
\hline Monetary Reward & 07 & .876 & 3.5429 & .76669 & 1 & & \\
Non-Monetary Reward & 09 & .879 & 3.6042 & .67692 & $.775^{* *}$ & 1 & \\
Employee Engagement & 17 & .930 & 3.5812 & .71791 & $.767 * *$ & $.765^{* *}$ & 1 \\
\hline$* \mathrm{P}<0.05, * * \mathrm{P}<0.01, * * * \mathrm{P}<0001$ & & & & &
\end{tabular}

The descriptive statistics on aggregate basis suggest that the perceived monetary reward $(\mathrm{M}=3.54, \mathrm{SD}=.76)$; and non-monetary reward $(\mathrm{M}=3.60, \mathrm{SD}=.67)$; is above medium level. Further, the employee engagement is also slightly above medium level $(\mathrm{M}=3.58, \mathrm{SD}=.71)$. The Cronbach alpha for the three variables are above 0.70 indicating good level of reliability for the survey measure adapted. The correlation suggest that monetary reward $(r=.767$, $\mathrm{P}<.05)$ and non-monetary reward $(\mathrm{r}=.765, \mathrm{P}<.05)$ are positively and significantly associated with employee engagement.

\section{Regression Analysis}

The regression analysis is used for testing the effects of monetary and non-monetary reward on employee engagement. Details are as under.

Table 5

Regression Analysis

\begin{tabular}{lcc}
\hline & Model I & Model II \\
\hline (Constant) & 3.375 & .615 \\
Gender Male & -.010 & -.015 \\
Bachelor & .051 & -.029 \\
Role Software-Developer \& Designer & .173 & .125 \\
Age 25 to 40 Years & .021 & -.230 \\
Monetary Reward & & $.426 * * *$ \\
Non Monetary Reward & & $.441^{* * *}$ \\
\hline R Square & .006 & .669 \\
F Stat & .244 & $51.645^{* * *}$ \\
\hline$* \mathrm{P}<0.05, * * \mathrm{P}<0.01, * * * \mathrm{P}<0001$ & &
\end{tabular}

In Model I, only control variables were entered, while, in model II, independent variables along with the control variables were entered. Results indicate that while controlling for the employee gender, qualification, job role, and age, monetary reward $(\beta=.426, \mathrm{P}<.05)$ and nonmonetary reward $(\beta=.441, \mathrm{P}<.05)$ has significant and positive effects on employee work engagement. Rsquare value shows that the monetary and non-monetary reward explains $66.9 \%$ change in the dependent variable of employee work engagement. The model is overall 
fit and significant (Fstat=51.645, $\mathrm{P}<.05)$. On the basis of these results, it can be concluded that the monetary reward as well as non-monetary reward are important contributors of employee work engagement among the staff of software development firms in Pakistan.

\section{Discussion}

The first objective of the study was to identify the gap between the offered and desired monetary and non-monetary reward for the employees in the software development firms in Pakistan. Our analysis suggest that there are several type of monetary reward such as enough payment, overtime payments, transportation allowance; and non-monetary reward such as social security, well-furnished offices, and appreciation and recognition which are preferred by the employees but not fully addressed by the employers. The second objective of the study was to test the role of reward practices offered by the software development firms as predictor of employee engagement. Regression analysis indicates that monetary reward as well as non-monetary reward has positive and significant effects on employee's level of engagement. The results are consistent with the findings of previous studies which found support for the role of monetary reward (Armstrong, 2007); and non-monetary reward (Jeffrey, 2002; Kube, et al., 2008; Steen, 1997). Our findings are also consistent with the findings of previous studies which found support for the relationship between reward practices and employee engagement (Hewitt, 2013; Waqas \& Saleem, 2014; Rao \& Shaikh, 2017).

\section{CONCLUSION}

The findings of the study leads to this conclusion that the reward practices are highly important in the software development firms' context. It can be concluded that there is mismatch between what employees prefers and what employer offers in terms of monetary and non-monetary reward. Furthermore, it can also be concluded that monetary reward alone is not enough and should be accompanied with the non-monetary reward. Thus, the software development firms should not only give importance to its monetary reward practices but should also be giving importance to the non-monetary reward practices. Furthermore, it can be concluded that both monetary as well as nonmonetary reward are important and lead to favorable employee outcome including employee engagement.

\section{Recommendations}

The following recommendations are made.

- Software development firms should offer more monetary reward to its staff including incentives, bonuses, and transportation allowances.

- The software developing firms should offer more non-monetary reward to its staff including social security, annual ceremony for employees, and appreciation and recognition.

- Employees may have different preferences for different type of reward so a tailored approach for offering reward is recommended over one reward package for all.

- The reward practices should not only be extended in terms of type but also in terms of coverage. Thus, reward offered should not only be limited to the selected staff but also be offered to broader categories of job. 


\section{Limitations}

The study limitations include use of survey method for data collection, small sample drawn from selected firms in a single city, and sole reliance on quantitative approach for data analysis.

\section{References}

AbuKhalifeh, A. N., \& Som, A. P. (2013). The antecedents affecting employee engagement and organizational performance. Asian Social Science, 9(7), 41-46.

Agrawal, S. (2010). Motivation and executive compensation. The IUP Journal of Corporate Governance, $9(1 \& 2), 27-46$.

Al-Nsour, M. (2012). Relationship between incentives and organizational performance for employees in the Jordanian universities. International Journal of Business and Management, 7(1), 78-89

Armstrong, M. (2007). Organization and People Employee Reward. Broadway Wimbledon: CIPD publishers.

Bakker, A. B. (2011). An evidence-based model of work engagement. Current Directions in Psychological Science, 20, 265-269

Benazir, \& Iqbal, N. (2015). Impact of rewards and leadership on the employee engagement in conventional banking sector of southern Punjab. International Letters of Social and Humanistic Sciences, 57, 30-34. doi:10.18052/www.scipress.com/ILSHS.57.30

Chaing, F.F., \& Birch, T.A. (2008). Achieving task and extra task related behaviors: a case of gender and position differences in the perceived role of rewards in the hotel industry. International Journal of Hospitality Management, 491-503.

Evenson, L. (2014). New frontiers in employee engagement. Retrieved from http:// www.bersin.com/News/Details.aspx?id=15208

Gallup. (2013). State of the global workplace: Employee engagement insights for business leaders worldwide. Retrieved from http://www. gallup.com/strategicconsulting/164735/state-global-workplace.aspx

Hofmans, J., De Gieter, S., \& Pepermans, R. (2013). Individual differences in the relationship between satisfaction with job rewards and job satisfaction. Journal of Vocational Behavior, 82, 1-9.

Jeffrey, S.A. (2002). The benefits of tangible non-monetary incentives. University of Chicago, 702-77.

Kube, S., Marechal, M. A. \& Puppe, C. (2008). The currency of reciprocity gift-exchange in the workplace. Working paper, Institute for Empirical Research in Economics, University of Zurich

Kumar, P., \& Swetha, G. (2011). A prognostic examination of employee engagement from its historical roots. International Journal of Trade, Economics and Finance, 2(3), 232241.

Luthans, F., \& Peterson, S. J. (2002). Recognition: a powerful but often overlooked, leadership tool to improve performance. The Journal of Leadership Studies, 7(1), 3139.

Maslach, C., Schaufeli, W. B., \& Leiter, M. P. (2001). Job burnout. In S. T. Fiske, D. L. Schacter, \& C. Zahn-Waxler (Ed.), Annual Review of Psychology, 52, 397- 422 
Mathauer, I., \& Imhoff, I. (2006). Health worker motivation in Africa: the role of nonfinancial incentives and human resource management tools. Human Resources for Health, 1-17.

Nienaber, R. (2010). The relationship between personality types and reward preferences (doctoral thesis), University of Johannesburg, Johannesburg, South Africa

Pakistan Software Export Board (2018). Pakistan Software Exports update. Retrieved from http://www.pseb.org.pk/about-us

Pfeffer, J. (1998). The human equation: Building profits by putting people first. Boston: Harvard Business School Press.

Ram, P., \& Prabhakar, G. (2011). The role of employee engagement in work-related outcomes. Interdisciplinary Journal of Research in Business, 1(3), 47-61.

Rao, G.K., \& Shaikh, M. (2017). To study the impact of monetary and non-monetary factors on employee engagement in IT sector. International Journal of Management Studies, 4(4), 137-145.

Saks, A. M. (2006). Antecedents and consequences of employee engagement. Journal of Managerial Psychology, 21(7), 600-619.

Schaufeli, W., Salanova, M., Gonzalez-Roma, V., \& Bakker, A. B. (2002). The measurement of engagement and burnout: A two sample confirmatory factor analytic approach. Journal of Happiness Studies, 3, 71-92.

Schaufeli, W.B. (2013). What is engagement? In C. Truss, K. Alfes, R. Delbridge, A. Shantz, \& E. Soane (Ed.), Employee engagement in theory and practice. (pp. 1-37). London: Routledge.

Shives, G. \& Scott, K. (2003). Gainsharing and EVA: The U.S. postal service experience. World at Work Journal, 23.

Sousa-Poza, A., Sousa-Poza, A. A. (2000). Well-being at work: a cross-national analysis of the levels and determinants of job satisfaction. Journal of Socio-Economics, 29, 517 538.

Steen, M. (1997). Job satisfaction is more than money and status. Infoworld, 19(43), 115.

Sundaray, B.K. (2011). Employee engagement: a driver of organizational effectiveness. European Journal of Business and Management, 3(8), 53-59

Sweeney, P., \& McFarlin, D. (2005). Wage comparisons with similar and dissimilar others. Journal of Occupation and Organizational Psychology, 78(1), 113-131.

Thomas, K.W. (2009). Intrinsic Motivation at Work (2nd ed.) Berrett-Koehler, San Francisco, CA.

Thompson, A., Strickland, A.J., Gamble, J.E. (2005). The quest for competitive advantage. New York: McGraw-Hill Irwin. Value Based Management.

Thumbran, R. S. (2010). Utilizing non-financial rewards as a competitive advantage in attracting and retaining employees. Gordon Institute of Business Science, University of Pretoria.

Wallace, W.J., \& Zeffane, R.M. (2001). Organizational behavior. a global perspective (2nd ed.). Australia: John Wiley \& Sons Australia Ltd.

Waqas, M., \& Saleem. M. (2014). The effects of monetary and non-monetary rewards on employee engagement and firm performance. International Journal of Business and Management, 6(31), 73-83. 